\title{
ANALIZA MODUS OPERANDI I PRÓBA USTALENIA MOTYWACJI SPRAWCY NA PODSTAWIE STUDIUM PRZYPADKU NIEWYJAŚNIONYCH ZBRODNI Z LODZI - KRYPTONIM „PARTNER”
}

\begin{abstract}
Streszczenie. Artykuł jest próbą interpretacji informacji zgromadzonych na podstawie treści materiałów naukowych, w konfrontacji z powszechnie dostępnymi doniesieniami prasowymi i plikami multimedialnymi, dotyczącymi największej niewyjaśnionej serii morderstw w historii polskiej kryminalistyki. Z uwagi na dobro śledztwa są one autoryzowanymi przez organy pracujące nad sprawą komunikatami, będącymi ułamkiem materiału zgromadzonego od czasu rozpoczęcia śledztwa, lecz wystarczającymi do zaspokojenia prawa do informacji publicznej, a także zwykłej ciekawości społecznej. Opierając się na powyższej dokumentacji, autor sformułował kilka pytań, na które stara się uzyskać odpowiedzi z powodu niekompletnego zarysu profilu sprawcy, zwłaszcza nieznanego jednostkom nieoperującym biegle w dziedzinach nauki, takich jak kryminologia, kryminalistyka, medycyna sądowa oraz psychologia kryminalna. Omówione zostały także zmiany następujące w związku z upływem czasu oraz nowe wątki wokół śledztwa.
\end{abstract}

Słowa kluczowe: zabójstwa homoseksualistów, Morderca z pikiety, kryptonim „Partner”, Morderca gejów z Łodzi, zbrodnie z Archiwum X.

\section{WPROWADZENIE}

Artykuł prezentuje spojrzenie na niewyjaśnioną dotychczas sprawę serii siedmiu morderstw, dokonanych w rejonie Łodzi na przełomie lat 1988-1993 przez nieustalonego sprawcę, któremu nadano pseudonim Mordercy z pikiety (Morderca gejów... 2017).

Łódź na przełomie transformacji ustrojowych zachodzących w naszym kraju była niemym świadkiem szeregu zbrodni, jakich dopuścił się nieuchwytny dla ówczesnych organów ścigania przestępca, wybierający na swoje ofiary osoby pochodzące z niemal hermetycznie zamkniętej grupy społecznej - mężczyzn o orientacji homoseksualnej. Schemat działania domniemanego zabójcy o przydomku „Roman” pozostawał wręcz identyczny: odbycie stosunku seksualnego z ofiarą,

* Krakowska Akademia im. Andrzeja Frycza Modrzewskiego, Wydział Prawa, Administracji i Stosunków Międzynarodowych, Katedra Kryminalistyki, Kryminologii i Nauk o Policji, tomaszberdzik@wp.pl. 
pozbawienie jej życia w wyszukany, nasycony brutalnością sposób, kradzież wartościowych przedmiotów i ucieczka z miejsca zdarzenia. Analizując modus operandi (Hanausek 1978, 200), autor niniejszego opracowania stara się ustalić determinanty przedkładające się na motywację sprawcy oraz odpowiedzieć na zasadnicze pytania: Czy był to sposób na zuchwały rabunek deficytowych dóbr materialnych? A może rozpaczliwe dążenie do zemsty na przedstawicielach łódzkiej społeczności homoseksualistów z powodu poczucia skrzywdzenia w przeszłości? Czy mamy do czynienia z pierwszym w Polsce odnotowanym przypadkiem seryjnego mordercy gejów?

Podjęte na wielką skalę akcje organów ścigania nie przyniosły rezultatu. W 2007 r. ze względu na specyficzny charakter sprawy została ona przekazana policjantom z łódzkiego Archiwum X (Pierzchała 2007). Artykuł przybliża chronologicznie wydarzenia składające się na całość największej niewyjaśnionej serii morderstw w historii polskiej kryminalistyki, począwszy od pierwszej zbrodni, a kończąc na ustaleniach, jakich udało się dokonać po dzień dzisiejszy. Postęp technologiczny, paradygmat kryminalistyki ewoluował znacznie na przestrzeni 29 lat - tyle bowiem upłynęło od popełnienia pierwszej zbrodni. Autor analizuje omawiany przypadek z wykorzystaniem używanych współcześnie nowoczesnych metod naukowych, nie waha się również przełamać tabu przewijającego się w tle sprawy i sięgnąć po studium przypadku innych spraw, w których można dostrzec podobieństwa do prezentowanej zagadki kryminalnej.

\section{PRÓBA USTALENIA TYPU SPRAWCY NA PODSTWIE LITERATURY NAUKOWEJ I ZGROMADZONYCH INFORMACJI}

W pochodzącym z 1980 r. biuletynie FBI opracowanym przez Hazelwooda i Douglasa $(1980,18-22)$ wyróżnia się dwa typy zabójców na tle seksualnym. Podział na sprawców zorganizowanych i zdezorganizowanych (Pastwa-Wojciechowska 2013, 136-142) został ukazany na podstawie interpretacji modus operandi (Wnorowski 1978, 39), a w szczególności w wyniku sformułowania podczas realizacji czynności procesowych, w tym śledztwa, szeregu istotnych pytań dotyczących zabójstwa: Czy wykazuje ono cechy planowania? Czy wybór miejsca zabójstwa niósł za sobą ryzyko identyfikacji sprawcy podczas jego dokonania? Czy corpus delicti nosi ślady tortur bądź inne formy obrażeń zadanych jeszcze za życia ofiary, czy już po jej uśmierceniu? Czy użyte narzędzie przygotowano wcześniej, czy może jest ono przypadkowym przedmiotem pochodzącym bezpośrednio z miejsca zdarzenia? Czy sprawca działa z dala od miejsca zamieszkania, na obcym terenie, czy też jest to przestrzeń dobrze mu znana, w której funkcjonuje na co dzień? Czy w toku czynności oględzin miejsca zdarzenia oraz zwłok zaobserwowano znamiona zacierania śladów? Ponadto próbuje się ustalić charakterystyczne cechy osobowościowe sprawcy. Osobowość - rodzaj zaburzenia, osobowość 
narcystyczna, psychopatyczna czy schizoidalna? Wygląd - zadbany, estetyczny, schludny czy zaniedbany, niechlujny? Relacje interpersonalne - skory do rozmów, łatwo nawiązuje relacje czy małomówny, wycofany z życia społecznego, interakcje $\mathrm{z}$ otoczeniem ogranicza do niezbędnego minimum? Sfera intymna - stosunek do płci własnej i przeciwnej związany z seksualnością, a także orientacją seksualną. Przedstawicieli której płci wybiera na ofiarę i jakie czynniki to determinują? Czy we wcześniejszym okresie życia wystąpiło zranienie na tle seksualnym, czy sprawca sam wcześniej był ofiarą molestowania seksualnego? Ewentualne naruszenia prawa i karalność przed popełnieniem zbrodni - jaki stosunek ma sprawca do ogólnie przyjętych reguł, norm obyczajowych i społecznych, a także zachowań niepożądanych, zagrożonych sankcją ze strony prawa karnego? Odnosi się do niego z poszanowaniem czy świadomie, cynicznie je lekceważy?

Nie ulega wątpliwości, że przytoczony powyżej podział na dwa typy zabójców odgrywa znaczącą rolę w profilowaniu kryminalnym (Gierowski, Jaśkiewcz-Obydzińska 2002, 79-95). Zestawienie wiadomości pozyskanych ze studium przypadku w wyniku postawienia powyższych pytań potwierdza specyfikę typu sprawcy jako mieszanego, niejednolitego, $\mathrm{z}$ uwagi na łączenie w sobie cech sprawcy zorganizowanego i niezorganizowanego (Widacki, Widła, Konieczny 2012, 12).

Czy zabójstwo wykazuje cechy planowania? Sposób pozyskania oraz wyboru ofiar o określonych cechach psychicznych i fizycznych, tj. gejów, może sugerować wstępne elementy planowania co do scharakteryzowania obiektu, który sprawca obiera za cel swoich poczynań.

Czy wybór miejsca zabójstwa niósł za sobą ryzyko identyfikacji sprawcy podczas jego dokonania? Zbrodnie miały miejsce w lokalach należących do ofiar, poza jedną z nich - dokonaną w lesie. Sprawca mógł zostać zidentyfikowany podczas uśmiercania ofiar. Tak wynika z informacji zgromadzonych za pośrednictwem Internetu, prasy i dokumentacji multimedialnej. Reasumując przebieg poszczególnych zbrodni, możemy uchwycić powtarzający się modus operandi sprawcy:

- napotkanie potencjalnej ofiary,

- zainteresowanie jej swoją osobą,

- odbycie stosunku seksualnego z ofiarą,

- pozbawienie jej życia w gwałtowny i nasycony brutalnością sposób,

- kradzież wartościowych przedmiotów należących do ofiary z jej mieszkania,

- podjęcie ewentualnej próby zatarcia śladów i ucieczka z miejsca zdarzenia.

Analizując dostępne materiały, możemy zauważyć niejednolity wymiar corpus delicti. Składają się nań zróżnicowane narzędzia, którymi posłużył się sprawca - były to: pospolity nóż kuchenny, sznurek, przewód elektryczny, pasek do spodni, knebel ze ścierki kuchennej, ponadto ofiary były duszone gołymi rękami, bite pięściami; niewykluczone, że morderca uderzał za pomocą ciężkich przedmiotów, tak aby ogłuszyć i uśmiercić swoje ofiary. Wymienione obiekty stanowiły elementy wyposażenia gospodarstwa domowego zamordowanych 
mężczyzn - zapewne zabójca sięgał po te, które w jego rozumieniu miały pozwolić na obezwładnienie ofiary i spowodować jej zgon. Sprawca nie posługiwał się charakterystycznym narzędziem, które umożliwiłoby jego identyfikację w przypadku ujawnienia kolejnych zbrodni (Konieczny, Szostak 2011, 56), co było charakterystyczne dla przypadków innych seryjnych morderców znanych historii kryminalistyki. Możemy zatem wnioskować, że użyte narzędzie nie było naszykowane w czasie poprzedzającym dokonanie zbrodni.

Czy sprawca dziala $z$ dala od miejsca zamieszkania, na obcym terenie, czy też jest to przestrzeń dobrze mu znana, w której funkcjonuje na co dzień? Rzeczywiste miejsce zamieszkania sprawcy nie zostało dotychczas ustalone. W rozmowie z jednym ze świadków, który przyprowadził go do mieszkania Kazimierza K., sprawca stwierdził, że mieszka z matką w rejonie ulicy Rzgowskiej. Nie można jednak orzec, czy oznajmienie to było prawdą, czy stanowiło jedynie próbę odwrócenia uwagi od innej dzielnicy miasta, gdzie mógł on zamieszkiwać i być łatwo rozpoznawalny dla społeczności sąsiedzkiej.

Obszarem działania sprawcy była Łódź, a dokładniej tzw. pikiety (Omyliński 2012), czyli miejsca spotkań homoseksualistów, gdzie umawiali się oni na spotkania towarzyskie bądź, znacznie częściej, na odbycie stosunku seksualnego. W owym czasie tego rodzaju popularnymi lokalizacjami były w szczególności m.in. dworzec Łódź Fabryczna, park miejski im. S. Moniuszki oraz plac H. Dąbrowskiego - to tam morderca po raz pierwszy nawiązywał kontakt z innymi mężczyznami. Można więc domniemywać, że owa przestrzeń była mu znana, choćby z uwagi na częstotliwość przebywania na jej terenie, ponadto można przyjąć założenie, iż sprawca poszukiwał kolejnych ofiar, lecz z powodu niesprzyjających okoliczności nie dopuścił się przeprowadzenia zamachu na ich życie. Następnie, zgodnie z opisanym schematem postępowania, najistotniejsze wydarzenia rozgrywały się w mieszkaniach uczestników pikiet - tam bowiem dochodziło do zabójstwa i kradzieży. Kiedy sprawca znajdował się w mieszkaniu ofiary, była to dla niego przestrzeń obca, stanowiąca nowość, mimo podobieństw w urbanistyce zabudowań z okresu PRL. Odbycie czynności seksualnej czy dokonanie zabójstwa nie pozostają obojętne dla osobowości człowieka, wyzwalają w nim szereg emocji, następuje wydzielanie hormonów oddziałujących na ośrodkowy układ nerwowy (dopamina, kortyzol) (Marek 1986, 21-26). Ponadto nieznane miejsce, obawa przed zaalarmowaniem sąsiadów reakcjami obronnymi ofiary wzmagały chaotyczne reakcje seryjnego mordercy, co zostało odzwierciedlone w bałaganie, jaki panował w lokalach należących do ofiar. Dodatkowym czynnikiem jest fakt dokonania kradzieży wartościowych dóbr należących do gospodarzy, co jest znamienne dla morderstw połączonych z kradzieżą (Kulicki, Kwiatkowska-Wójcikiewicz, Stępka 2009, 26).

Czy na zwłokach ujawniono ślady tortur bądź inne formy obrażeń zadanych jeszcze za życia ofiary, czy już po ich uśmierceniu? Ofiary ginęły wskutek gwałtownego i brutalnego działania sprawcy (Ptak 2015, 96-110). Obrażenia 
zadawane były energicznie, co świadczy o zdeterminowaniu mordercy - w przypadku zabójstwa aktora łódzkiej estrady cios nożem był na tyle silny, iż przebił ciało mężczyzny na wylot (Magazyn Kryminalny 997, 9 kwietnia 2008, TVP). Innym razem sprawca zadał sześć ciosów w klatkę piersiową oraz śmiertelny - centralnie w serce. Jedna z ofiar została skrępowana kablem elektrycznym, kolejna straciła życie w wyniku uduszenia kneblem sporządzonym z kuchennej ścierki. Uszkodzenia organizmu u denatów odzwierciedlają zachowanie sprawcy: stanowcze i silne uderzenia mogą świadczyć o bezwzględności oraz agresji - tak można opisać stan psychiczny i emocjonalny towarzyszący sprawcy w chwili dokonania zbrodni (Heitzman 2002, 120-252).

Z chwilą śmierci bądź procesu agonalnego ofiar sprawca ukierunkowywał przedmiot swoich zainteresowań na przeszukiwanie lokalu, w którym doszło do tragicznych wydarzeń, pod kątem znalezienia kosztowności i przedmiotów pożądanych na rynku wtórnym. Zwłoki były częściowo obnażone - w tym miejscu należy zaznaczyć fakt, iż w chwili ujawnienia zwłok niektóre ofiary miały na sobie bieliznę, inne były rozebrane z koszuli, zaś ciało jednego z denatów znalezione w pościeli na łóżku było w pełni roznegliżowane. W toku czynności procesowych nie doszukano się uszkodzeń narządów płciowych (Konopka, Woźniak, Kunz 2009, 78-84) bądź sfer erogennych, co jest znamienne dla morderstw z lubieżności oraz sprawców dopuszczających się ataków na tle seksualnym, z ofiarami gwałtów i molestowania seksualnego włącznie (McCabe, Wauchope 2005).

Czy w toku czynności oględzin miejsca zdarzenia oraz zwłok zaobserwowano znamiona zacierania śladów? (por. Rydzek 1984, 89-105). Sąsiadka pierwszej z ofiar zaalarmowała milicję o tym, że z mieszkania mężczyzny wyczuwalna jest nieprzyjemna woń (w późniejszym etapie czynności stwierdzono, że odpowiedzialny za nią był proces gnilny zwłok oraz ulatniający się z kuchenki gaz ziemny). Denat został przygnieciony regałem. W trakcie oględzin ujawniono materiał daktyloskopijny w postaci odcisków linii papilarnych, ponadto spośród znalezionych butelek po alkoholu i niedopałków papierosów można byłoby wyizolować materiał do badań DNA. W 1992 r. zwłoki Jana D. zostały przykryte poduszkami i kołdrą, które następnie zostały podpalone, jednak ogień nie rozprzestrzenił się na pozostałe elementy wyposażenia lokalu. Przykrycie ściółką leśną zwłok Jakuba M., ze względu na miejsce popełnienia zbrodni wyłamuje się z dotychczasowego schematu, jaki cechował sprawcę.

Osobowość - rodzaj zaburzenia, osobowość narcystyczna, psychopatyczna czy schizoidalna? Wygląd - zadbany, estetyczny, schludny czy zaniedbany, niechlujny? Podejrzany potrafił nawiązać kontakt z przedstawicielami tej samej płci, więc zapewne starał się sprawiać pozytywne wrażenie jako potencjalny kochanek, tak aby być atrakcyjnym dla swoich ofiar. Prawdopodobne jest to, iż działał według określonego scenariusza, aby nie wzbudzić podejrzeń odnośnie do swoich rzeczywistych zamiarów. Kluczowa zmiana zachowania następowała w trakcie lub po stosunku seksualnym - wówczas sprawca tracił kontrolę nad 
racjonalnością swoich odruchów, która zostały wyparta przez silne ładunki emocjonalne w postaci agresji i przemocy, o czym świadczą obrażenia ujawnione na zwłokach denatów (Leszczyński, Hanausek 1995, 7-44).

Relacje interpersonalne - skory do rozmów, latwo nawiązuje relacje czy małomówny, wycofany $z$ życia społecznego, interakcje z otoczeniem ogranicza do niezbędnego minimum? Świadkowie mający bezpośredni kontakt z typowanym mężczyzną zeznali, że był on powściągliwy w rozmowach dotyczących swojej osoby, a jego wypowiedzi były lakoniczne - nie sposób ustalić, czy niosły prawdziwą wartość logiczną. Ze względu na nieznaną tożsamość, niejawne pozostają jego dane personalne, wykształcenie, zawód i inne cechy charakterystyczne przydatne dla profilera, a także zawężające krąg poszukiwanych (Konieczny, Szostak 2011, 67).

Sfera intymna - stosunek do płci własnej i przeciwnej związany z seksualnością, a także orientacją seksualną. Przedstawicieli której płci wybiera na ofiarę i jakie czynniki to determinują? Czy we wcześniejszym okresie życia wystąpilo zranienie na tle seksualnym, czy sprawca sam wcześniej był ofiarą molestowania seksualnego? W trakcie jednego z przyjęć organizowanych w towarzystwie kręgu znajomych ofiary zauważono, że w obecności kobiet „Roman” był onieśmielony, nie chciał tańczyć, po wypiciu wspólnego bruderszaftu odmówił pocałunku kobiecie. Uściślając - w środowisku kobiet czuł się niepewnie, nie wykazywał woli integracji z płcią przeciwną, pod względem interpersonalnym znacznie pewniej funkcjonował $\mathrm{w}$ gronie mężczyzn (Zabójca z pikiety 2017). W zbiorze jednostek, jakie poniosły śmierć z jego ręki, znajdują się wyłącznie przedstawiciele płci męskiej.

Jeden z przygodnych partnerów seksualnych, który nie zgodził się na przenocowanie domniemanego mordercy mimo jego usilnych staran, zeznał w toku śledztwa, że gdy wyraził zaskoczenie faktem znajomości wielu technik cielesnych, usłyszał znamienne stwierdzenie: „Robię to od lat. Jak miałem piętnaście lat, to zgwałcił mnie wychowawca z poprawczaka" (Strzelecka 2008). Można zatem domniemywać, że traumatyczne przeżycia z przeszłości mogły zachwiać równowagą psychofizyczną sprawcy, wpłynąć na jego kondycję psychoseksualną oraz doprowadzić do rozwoju nieprawidłowej osobowości wraz z kształtowaniem się parafilii i dewiacji (Choromańska, Mocarska 2009, 37).

Ewentualne naruszenia prawa i karalność przed popelnieniem zbrodni - jaki stosunek ma sprawca do ogólnie przyjętych regul, norm obyczajowych i społecznych, a także zachowań niepożądanych, zagrożonych sankcją ze strony prawa karnego? Odnosi się do niego z poszanowaniem czy świadomie, cynicznie je lekceważy? Między 1988 a 1993 r. sprawca dopuścił się szeregu poczynań wyczerpujących w pełni znamiona czynu zabronionego. Nie poprzestał na jednym morderstwie, dokonując kolejnych, ponadto usiłował bezskutecznie i prymitywnie zatrzeć ślady zbrodni, zaś wielokrotna kradzież wartościowego mienia $\mathrm{w}$ postaci rzeczy ruchomych znajdujących się w posiadaniu ofiar stanowiła 
przestępstwo na gruncie ówczesnego Kodeksu karnego. Niewykluczone zatem, że sprawca dopuszczał się w okresie poprzedzającym pierwszą zbrodnię innych występków, które z uwagi na mniejszą rangę niż morderstwo nie zostały mu przypisane, bądź też nie zostały ujawnione i wpisują się w katalog ciemnej liczby przestępstw.

\section{ROZBIEŻNOŚCI W PORTRECIE PAMIĘCIOWYM}

Sporządzony na postawie zeznań naocznych świadków portret pamięciowy sprawcy ewoluował na przestrzeni czasu, jaki upłynął między pierwszą a ostatnią zbrodnią (Interwencja 2013). Początkowo poszukiwano młodego mężczyzny, przejawiającego następujące cechy: w wieku powyżej dwudziestego roku życia, o krępej budowie ciała, włosy koloru blond z charakterystycznymi lokami, zadbany, młodzieńczy wygląd, ubrany w markową odzież (kurtka dżinsowa z kożuszkiem), obuty w lakierki z białymi czubkami, przyciągał uwagę innych swoją osobą. Późniejszy obraz sprawcy stanowił swego rodzaju przeciwieństwo pierwotnie sporządzonego rysopisu. Mężczyznę wyróżniały ciemniejsze włosy, wzrost 176-178 cm, przedział wiekowy 27-30 lat, przedstawiał się posługując imieniem „Roman”. Znaki szczególne wizerunku postaci to tatuaże: pierwszy - kropka na grdyce, w slangu więziennym oznaczająca pijaka; kolejny - umiejscowiony na zewnętrznym kąciku oka, oznaczający w tym samym dialekcie męską prostytutkę. Jednostki, które widziały go z bliska, zapamiętały ubiór nieadekwatny do pogody, zaniedbany wygląd, dodatkowo brak pieniędzy na bilet komunikacji nocnej i kupno papierosów (Masłowski, Urazińska, Walczyk 2010).

Wydaje się, że we wczesnym okresie śledztwa sprawcy dobrze się powodziło, o czym świadczy jego zadbany wygląd, dłuższe włosy oraz dobrze zbudowana sylwetka ciała - możliwe, że nie wykonywał określonych profesji, takich jak praca na budowie i podobne, nieobojętne dla estetycznego wizerunku (np. spracowane dłonie, krótsze włosy, ewentualne blizny).

Ogólnodostępne materiały filmowe poświęcone sprawie zawierają wypowiedź śledczych stanowiącą hipotezę odnośnie do wspomnianego stanu wizualnego osobnika, utrwalonego z użyciem portretu pamięciowego. Funkcjonariusz sugeruje, iż nieszablonowa postura mogła być spowodowana faktem bycia utrzymywanym przez innego mężczyznę, który dokładał starań, aby młodzieniec wyglądał estetycznie i ponosił nakłady finansowe na odzież wysokiej jakości (Interwencja 2013). Oczywistym jest także przypuszczenie, że wspomniana wysokogatunkowa konfekcja mogła stanowić przedmiot przestępstwa i zostać zdobyta w wyniku kradzieży.

Na późniejszym etapie akcji o kryptonimie „Partner” deskrypcja mężczyzny była sprzeczna z pierwowzorem. Stan ów mógł być spowodowany nie tylko oczywistym procesem starzenia się organizmu, lecz także konsekwencjami 
stosowania używek w postaci alkoholu i papierosów - obecnych w miejscach popełnienia zbrodni. Ponadto odnotowano fakt pożyczania przez mężczyznę pieniędzy na zakup paczki papierosów (Interwencja 2013). Pogorszony komfort życia, spowodowany niestabilną sytuacją finansową, mógł dodatkowo determinować zbrodniczy proceder sprawcy. Obuwie nieadekwatne do pory roku oraz skromny ubiór wskazują na prawdziwość powyższego założenia.

Modyfikacje skóry w postaci tatuaży mogą sugerować przebywanie w zakładzie karnym, jednak nie przesądzają całkowicie o tego rodzaju okolicznościach. Tatuaże mogły zostać wykonane poza murami jednostki penitencjarnej. Jeden z nich, znajdujący się na dłoni, nosił ślady nieumiejętnego usuwania - być może był on na tyle charakterystyczny, iż skłonił sprawcę do podjęcia próby uczynienia go nieczytelnym, tak by zmniejszyć prawdopodobieństwo identyfikacji na podstawie tego znaku szczególnego.

\section{PRAWDOPODOBNE DETERMINANTY KSZTALTUJĄCE MOTYWACJĘ SPRAWCY}

Założenie jednego czynnika skłaniającego sprawcę do dopuszczania się przestępczego procederu stanowiłoby kluczowy błąd nie tylko w trakcie śledztwa, lecz także podczas próby skoncentrowania się nad całym uniwersum sprawy. Przypadki opisane w literaturze naukowej wskazują bowiem, iż motywacja sprawców bardzo często nie ogranicza się do jednej z pobudek, ale może łączyć kilka czynników powiązanych ze sobą w większym lub mniejszym stopniu (Turvey 2001, 7-13).

W związku z powyższym stwierdzeniem, ze względu na złożony charakter sprawy, można podać hipotetyczne założenia dotyczące całokształtu domniemanej motywacji sprawcy:

- pragnienie zemsty w stosunku do ogółu homoseksualnej społeczności (na jednym z towarzyskich spotkań z ust „Romana” miały paść słowa o gwałcie, jakiego dopuścił się na nim wychowawca z poprawczaka, kiedy przebywał w Ignacewie i miał 15 lat); u sprawcy mogła występować reminiscencja faktów z przeszłości - cykliczny motyw zbrodni może sugerować odtwarzanie pewnych ról, wzmocnienie bodźców oddziałujących na sferę seksualności, zabójstwo będące efektem rozładowania napięcia seksualnego, psychicznego i emocjonalnego;

- pragnienie ukarania innych homoseksualistów w przypadku wcześniejszego zarażenia sprawcy wirusem HIV - piętno śmiertelnej choroby i bezradność wobec niej mogły spowodować kumulację frustracji, przejawiającej się uporczywymi myślami o zdawaniu bólu, stosowaniu przemocy wobec jednostek, które wybierał na cel, obwiniając je za nieuleczalną chorobę; dodatkowo wizja nieuniknionej śmierci powodowałaby brak obawy przed represją w postaci obowiązującej wtedy kary śmierci;

- przypuszczalny brak akceptacji własnej orientacji seksualnej, wywołujący wrogość wobec homoseksualnej społeczności; 
- motyw ekonomiczny - głównym celem była kradzież cennych dóbr materialnych, a zabójstwo skutkiem ubocznym (gdyby jedna z ofiar, związana paskiem do spodni i skrępowana sznurkiem, nie zadławiła się kneblem z kuchennej ścierki, być może miałaby szansę przeżyć na tyle długo, aby otrzymać stosowną pomoc).

\section{OFIARY W UJĘCIU WIKTYMOLOGICZNYM}

Z uwagi na wielowątkowość i skomplikowany charakter sprawy należałoby rozpatrywać ją pod względem wiktymologicznym, dokonując dychotomicznego podziału na wiktymologię ogólną (obejmującą całokształt przedmiotowej materii) i wiktymologię indywidualną (skupiającą się na każdej z ofiar jako odrębnym przypadku rozważanym niezależnie od reszty) (Bieńkowska 2000, 70).

Brunon Hołyst sformułował pojęcie zjawiska zwanego potencjałem wiktymogennym (Hołyst 2000, 30-56). W uproszczonym rozumieniu definiujemy ów potencjał jako zespół cech i warunków życia, które zwiększają prawdopodobieństwo podatności na stanie się ofiarą przestępstwa. Hołyst wyróżnia także cechy kondycji społecznej - kategoria ta dotyczy osób mogących stać się ofiarą ze względu na swój status społeczny oraz kondycję zawodową. Często sprawca wybiera taką osobę z uwagi na bezkarność i nikłe zainteresowanie jednostką, zwłaszcza jeżeli ta przejawia skłonność do alienacji i preferuje utrzymywanie relacji z niewielkim kręgiem osób. Każdego z zamordowanych mężczyzn charakteryzowała wspólna cecha - orientacja homoseksualna (Morderca gejów... 2017). Ofiary odróżniał status społeczny i wykonywany zawód (aktor, właściciel smażalni, przewodnik turystyczny, handlarz, emeryt), a także stosunek do własnej orientacji seksualnej, która w okresie PRL stanowiła jeden z tematów tabu. Zróżnicowane cechy charakteru i osobowości mężczyzn można wykazać, zestawiając ich na zasadzie podobieństw i kontrastów. Jeden z nich nie ukrywał swoich preferencji seksualnych, nie była mu obca społeczność ówczesnych pikiet, inicjował imprezy towarzyskie i był nieostrożny w kontaktach międzyludzkich. Natomiast inny z mężczyzn ukrywał swoją sferę seksualną nawet przed najbliższymi osobami z kręgu rodziny i współpracowników. Jedyną uroczystością obchodzoną corocznie w większym gronie były jego imieniny, unikał miejsc schadzek łódzkich homoseksualistów. Ponadto, mężczyźni prosperowali odmiennie pod względem finansowym (Magazyn Kryminalny 997, 13 marca 2008, TVP). Jeden z nich posiadał kosztowności w postaci biżuterii, oszczędności w walucie i dewizach depozytowych, zaś Kazimierz K. wiódł skromny żywot emeryta (Strzelecka 2008).

Pomimo powyższych rozbieżności, sprawca miał świadomość, że grupa społeczna homoseksualnych mężczyzn zazwyczaj żyje na wyższym poziomie egzystencjalnym niż mężczyźni heteroseksualni będący mężami i ojcami, którzy ponoszą nakłady na utrzymanie rodziny i gospodarstwa domowego. Spośród zamordowanych tylko jeden mężczyzna miał wcześniej żonę, a w okresie 
poprzedzającym śmierć jego stan cywilny był określony jako „,rozwiedziony”. Samotny tryb życia, brak stałych partnerów i potomstwa do utrzymania umożliwiał znacznie dostatniejsze życie niż to, które wiodą mężczyźni posiadający własną rodzinę bądź rozwiedzeni, opłacający alimenty na swoje potomstwo.

Możemy zatem odnotować wysoki współczynnik wiktymogenny, uwarunkowany nie tylko uprzedzeniami, ostracyzmem, przemocą czy skrajną nienawiścią (Lipowska-Teutsh, Ryłko 2007, 8-12), lecz także lepszą stopą życiową w porównaniu do innych obywateli. Dodatkowym determinantem wpływającym na wzrost tego współczynnika jest podejmowanie wysoce ryzykownych zachowań ze strony ofiar. W omawianym studium przypadku mężczyźni zapraszali nowo poznanego osobnika do swojego mieszkania w celu zaspokojenia swojego popędu seksualnego, nie znając nawet rzeczywistych personaliów tej osoby. Zachowanie to możemy określić jako wysoce nierozważne, lekkomyślne, świadczące o nieostrożności i niezachowaniu podstawowych reguł bezpieczeństwa. Świadczy o tym już sam fakt spożywania z obcą osobą alkoholu, który zaburza prawidłowe funkcjonowanie ośrodkowego układu nerwowego, a co za tym idzie - także podejmowanie skutecznych działań obronnych w sytuacji zagrożenia. Kolejnym czynnikiem wzmagającym potencjał wiktymologiczny osób reprezentujących homoseksualną społeczność jest nieufność do organów ścigania, przejawiająca się m.in. niechęcią do podjęcia współpracy, nawet w przypadku pokrzywdzenia przestępstwem. Nie można zatem wykluczyć przypuszczenia, że nastawienie tych osób do ówczesnego aparatu bezpieczeństwa w postaci Milicji Obywatelskiej było znane sprawcy, co ów cynicznie wykorzystywał, gdyż dawało mu ono poniekąd pewną przewagę i zwiększało swobodę działań.

\section{WPLYW AKCJI „HIACYNT” NA PRZEBIEG ŚLEDZTWA}

Dokonując analizy przebiegu wydarzeń składających się na omawiane studium przypadku, nie można pominąć szeregu uwarunkowań wpływających istotnie na model i późniejszy przebieg śledztwa. Niezwykle relewantną okolicznością dla ogółu sprawy była zainicjowana przez gen. Czesława Kiszczaka, przeprowadzona na przestrzeni lat 1985-1987 akcja o kryptonimie „Hiacynt”, wymierzona w środowisko osób homoseksualnych będących obywatelami PRL (Milcke 2015). Propagandowym uzasadnieniem podjętych działań Milicji Obywatelskiej i Służby Bezpieczeństwa miało być „przeciwdziałanie rozwojowi epidemii AIDS na terenie Polski, kontrola wysoce kryminogennego środowiska oraz walka z prostytucją”. W rzeczywistości jednak poczynania te doprowadziły do ciągu nadużyć w postaci inwigilacji i szantażu osób podejrzewanych o związek z gejowskim środowiskiem oraz werbowania tajnych współpracowników.

Przechodząc ad rem, można stwierdzić, że zestawienie akcji „Hiacynt” o ogólnokrajowym zasięgu z czynnościami operacyjnymi o kryptonimie „Partner”, 
prowadzonymi głównie na terenie województwa łódzkiego, pozwala na wskazanie ujemnego (czyli wpływającego negatywnie na rozwój śledztwa) oraz dodatniego aspektu podjętych działań (ułatwienie procedur podejmowanych przez organ procesowy).

Aspekt negatywny: hermetycznie zamknięta grupa społeczna - mniejszość seksualna składająca się mężczyzn - stała się jeszcze bardziej nieufna do organów milicji obywatelskiej, co znacznie utrudniało działania zmierzające do poszukiwania i ujęcia domniemanego sprawcy zabójstw ofiar zaliczających się do tej zbiorowości. W reportażu zrealizowanym przez media pada stwierdzenie o napotkaniu ,muru” ze strony przesłuchiwanych na okoliczność posiadania informacji przydatnych w śledztwie. Ponadto, wypowiadający te słowa wspomina, iż widoczna niechęć do współpracy, wyrażająca się w embargu informacji, trwa również w czasach współczesnych (Interwencja 2013). Powyższe fakty stanowią potwierdzenie założeń przyjętych w opracowaniu. Artykuł prasowy odnosi się do przebiegu gromadzenia informacji przez śledczych. Przesłuchiwani mężczyźni odpowiadali niechętnie, wyłącznie na zadawane pytania, nie wykazywali inicjatywy, aby przyczynić się do ujęcia sprawcy, nie dzielili się własnymi spostrzeżeniami znanymi we własnym towarzystwie. Swoista zasłona milczenia po stronie reprezentantów tego grona mogła wynikać z obawy przed wyjawieniem kompromitujących, w ich mniemaniu, faktów dotyczących sfery osobistej i życia seksualnego - należy bowiem pamiętać, że przynajmniej część tych osób pełniła funkcje zaufania publicznego, wymagające nieposzlakowanej opinii, a ujawnienie tego rodzaju informacji mogłoby skutkować ostracyzmem ze strony współpracowników lub utratą pracy.

Jak już wyżej wspomniano, działania organów państwowych mogły też wpłynąć pozytywnie na całokształt przedmiotowej sprawy. Wytyczne akcji „Hiacynt" przewidywały wykonanie określonych procedur, w tym sporządzenie - ujmując to językiem potocznym - tzw. różowych teczek. Z punktu widzenia pracy śledczego polegało to na stworzeniu zbioru $z$ danymi osobowymi gejów i osób typowanych jako powiązane $\mathrm{z}$ ich środowiskiem. Na terenie województwa łódzkiego taki zbiór mógł przyczynić się do zawężenia kręgu podejrzewanych osób i skonkretyzowania cech szczególnych mężczyzny zgodnego ze stworzonym portretem pamięciowym - część mężczyzn miała zakładaną kartę homoseksualisty i została poddana procedurze daktyloskopowania (Akcja... 2017). Dodatkowo, opisany wyżej rejestr umożliwiał przeszukiwanie katalogów o zasięgu ogólnopolskim dotyczących przestępstw, w wyniku których poszkodowani zostali bądź dokonali ich homoseksualiści - co w przypadku wystąpienia podobieństw między zdarzeniami z województwa łódzkiego a tymi z innych województw sugerowałoby, iż sprawca był mobilny i nie ograniczał się w swym działaniu do jednej przestrzeni. Za przykład niestacjonarnego sprawcy może posłużyć postać polskiego gwałciciela i zabójcy Leszka Pękalskiego, podróżującego po kraju głównie pociągami (Leszek... 2017). Ponadto, informatorzy będący współpracownikami 
Służby Bezpieczeństwa zwerbowani podczas akcji mogli podzielić się informacjami w zakresie szczegółów z życia ofiar i zwyczajów panujących na pikietach, włączając $\mathrm{w}$ to doniesienia dotyczące serii morderstw wymieniane wyłącznie między osobami tej samej płci, niedostępne dla ludzi niezwiązanych ze środowiskiem mniejszości seksualnej. Zgromadzone materiały, zarchiwizowane obecnie w Instytucie Pamięci Narodowej, współcześnie mogłyby posłużyć jako materiał poszlakowy, który należałoby poddać analizie pod kątem zbliżonych przestępstw, w których przewija się homoseksualny wątek.

\section{PODOBNE ZBRODNIE}

Przy analizowaniu zagadnień łączących się z tematyką niniejszego opracowania, zaniedbaniem byłoby skupienie się wyłącznie na województwie łódzkim, z uwagi na prawdopodobne istotne czynniki, takie jak: mobilność sprawcy związana z przestępczym procederem o zasięgu ogólnokrajowym, zabójstwo podyktowane względami ekonomicznymi, czyli motyw rabunkowy oraz możliwość niewykrycia kolejnych zabójstw przy założeniu, że sprawca mógł modyfikować swój sposób działania tak, aby następne zbrodnie odbiegały znacząco od dotychczasowych, co przyczyniłoby się do utrudnienia procesu jego poszukiwania przez organy ścigania. Poniżej scharakteryzowane zostaną przypadki zabójstw mające co najmniej kilka wspólnych elementów tożsamych $\mathrm{z}$ analizowanym studium przypadku o kryptonimie „Partner”.

Pierwsza z podobnych zbrodni miała miejsce 13 sierpnia 1985 r. w Warszawie. 35-letni kinooperator Edward R. około godziny trzeciej w nocy sprowadził do lokalu, który zamieszkiwał wraz z matką, młodego mężczyznę. Mniej więcej o godzinie szóstej rano matka usłyszała krzyk i odgłosy szamotaniny, dostrzegła zakrwawionego syna oraz młodzieńca, który na jej widok uciekł. Mimo wezwania pogotowia i podjętych działań ratunkowych, życia mężczyzny nie udało się uratować. Śmierć nastąpiła wskutek ciosu nożem. Podczas oględzin ujawniono liczne odciski palców i sporządzono portret pamięciowy na podstawie zeznań matki denata - portret ten został następnie opublikowany na łamach prasy. Rekonstrukcja omawianego zdarzenia była także prezentowana w telewizji w Magazynie Kryminalnym 997 w 1989 r. dla liczniejszego grona odbiorców (zob. Magazyn Kryminalny 997, 8 maja 2008, TVP). Śledztwo zostało umorzone z powodu niewykrycia sprawcy. W styczniu 2007 r. dzięki systemowi AFIS (automatyczny system identyfikacji daktyloskopijnej) udało się wytypować profil daktyloskopijny zgodny z materiałem pobranym $\mathrm{w}$ trakcie oględzin (Włodarczyk 2007, 159-165). Mężczyźnie przedstawiono zarzuty. Sąd, po zapoznaniu się ze sprawą i wysłuchaniu oskarżonego, stwierdził przekroczenie obrony koniecznej spowodowanej napastliwym zachowaniem ofiary i, uwzględniając powyższe, wydał wyrok uniewinniający. 
Następna zbrodnia o cechach wspólnych z przedstawianą serią zabójstw wydarzyła się już w nowym ustroju politycznym i została ujawniona 12 lutego 1993 r. Denat, podobnie jak jedna z ofiar pochodząca z Łodzi, nie ujawniał swojej orientacji seksualnej w otoczeniu współpracowników, natomiast w środowisku lubelskich homoseksualistów, którzy nadali mu pseudonim ,Wanda”, postrzegany był jako „król” (Kasperska 2014). Mężczyzna przebywał często w okolicach szaletu miejskiego, który można by nazwać odpowiednikiem łódzkiej pikiety. Nie narzucał propozycji seksualnych nowo poznanym osobom i potrafił pogodzić się z odpowiedzią odmowną.

Przyczyną śmierci Jerzego K. było wykrwawienie się, spowodowane licznymi obrażeniami głowy zadanymi szklaną butelką i łomem, zaś wokół szyi zmarłego owinięto pętlę ze sznurka. Mieszkanie nie było zamknięte na klucz, skradzione zostały przedmioty mające odzwierciedlenie w sporej ilości pieniędzy i będące wyznacznikiem zamożności (sprzęt elektroniczny, zbiory numizmatyczne, elementy garderoby oraz kasety VHS). Śledztwo wykazało, iż zabójcą był Dariusz R. - mężczyzna ten znał ofiarę od pięciu lat, sprowadzał do jej mieszkania potencjalnych partnerów seksualnych, przyjmując za to korzyści finansowe. Funkcjonariusze zatrzymali złodziei i paserów zmierzających do odebrania skradzionego mienia, a chcąc powiadomić prawowitego właściciela, natrafili na jego zwłoki.

\section{WNIOSKI I SPOSTRZEŻENIA}

Tok rozumowania oparty na upublicznionych informacjach i lekturze literatury naukowej pozwala na poczynienie spostrzeżeń mogących ukierunkować charakter analizowanej sprawy. Poniżej zostaną wyodrębnione wybrane przez autora istotne kwestie.

W omawianym przypadku sposób działania przestępcy był modyfikowany - ofiary ponosiły śmierć w trakcie stosunku seksualnego lub zaraz po nim, co sugeruje występowanie zaburzeń seksualnych u sprawcy, oddziałujących w znacznym stopniu na jego zachowanie. Zabójstwo Jakuba M., dokonane w jego samochodzie w lesie, wyłamuje się ze schematu obchodzenia się z ofiarą przed uśmierceniem jej (zabójstwo bezpośrednio po seksualnych uniesieniach) oraz miejsca dokonania zbrodni (zwykle w mieszkaniach ofiar). Możliwe, że sprawca potrafi uwzględnić ryzyko zdemaskowania go i złapania na gorącym uczynku (byłoby to wysoce prawdopodobne w przypadku wspomnianego denata, gdyż zamieszkiwał on z rodzicami - w sytuacji zaatakowania ich syna zostaliby oni zaalarmowani odgłosami walki, krzykiem, przemieszczaniem się przedmiotów potrąconych wskutek reakcji obronnych ofiary; zapewne pospieszyliby na pomoc i wezwali milicję/ policję, a także zapamiętali wygląd sprawcy), jak również umie zapanować na swoim popędem na tyle, by zabicie ofiary odłożyć na dogodny moment podczas przebywania w jej otoczeniu (Pastwa-Wojciechowska 2013, 136-147). 
Niejednolite zachowanie po dokonaniu zbrodni, przejawiające się niekonsekwencją w zacieraniu śladów, powinno zaowocować refleksją: Czy takie postępowanie to wyraz zwyczajnego niedbalstwa, oddziaływania stresu (Heitzman 2002, 120) i wyłączenia racjonalnego myślenia, czy może sprawca świadomie różnicuje swoje czynności, tak aby zmylić poszukujących go funkcjonariuszy? Niekonsekwentny sposób zachowania przestępcy obserwujemy np. w sytuacji, gdy dla zatarcia śladów usiłował wzniecić pożar lokalu, zaś innym razem odkręcił kurki z gazem, a po dokonaniu zabójstwa porzucił klucze do mieszkania denata na korytarzu, prawdopodobnie zostawiając swoje odciski palców (jednak wskutek kontaktu z nimi sąsiadów zamordowanego nastąpiła kontaminacja, uniemożliwiająca uzyskanie fragmentu odcisku zdatnego do utrwalenia go za pomocą technik kryminalistycznych i - współcześnie - wprowadzenia do elektronicznej bazy systemu AFIS).

Kradzież albumu ze zdjęciami należącego do jednej z ofiar skłania do postawienia pytania: Czy podczas spotkania imieninowego, na którym obecni byli m.in. sprawca, ofiara i jej znajomi, mogący opisać zachowanie „Romana” i podać jego znaki szczególne (co nastąpiło w trakcie składania zeznań), wykonano fotografie, utrwalając wizerunek sprawcy - zatem kradzież albumu była podyktowana obawą przed ujawnieniem powyższego faktu organom ścigania, mogącym przeglądać zbiór ze zdjęciami w trakcie oględzin miejsca zbrodni? Możliwe jest również, że zabierając album, sprawca chciał się dowiedzieć, jak wyglądają pozostali znajomi ofiary $\mathrm{z}$ kręgu homoseksualnego, tak aby na podstawie fotografii wykonanych w mieszkaniu oszacować, czy dana osoba jest zamożna i czy mogłaby być opłacalna napaść na nią z pobudek ekonomicznych.

Kolejnym przedmiotem skradzionym z miejsca zbrodni, istotnym dla śledztwa, jest notes zawierający dane osobowe w postaci adresów i numerów telefonów wraz z przypisanymi do nich imionami i nazwiskami osób powiązanych $z$ denatem. Pomijając członków rodzin oraz kobiety, dla sprawcy interesujące mogły być wpisy zawierające kontakty do innych mężczyzn, zwłaszcza jeżeli ofiara oznaczała je w określony sposób, mogący jednoznacznie sugerować ich orientację homoseksualną - co ułatwiałoby przestępcy wyszukanie kolejnej ofiary. Co ciekawe, w mieszkaniu innego zamordowanego mężczyzny ujawniono podobny notatnik zawierający wspomniane wyżej dane. Nie wiadomo, dlaczego sprawca go nie zabrał - czy skoncentrował się na cenniejszych przedmiotach, mających wymierną wartość pieniężną, czy zwyczajnie go przeoczył. Nie przeoczyli go jednak funkcjonariusze, wykorzystując zawartość notesu do skontaktowania się z potencjalnymi ofiarami i pozostałymi obywatelami figurującymi w tym zbiorze wpisów (Zabójca z pikiety 2017).

Niewątpliwie rażącym zaniedbaniem, rzucającym cień na działania podejmowane w celu wykrycia sprawcy, było opublikowanie portretu pamięciowego na łamach prasy dopiero po ostatnim zabójstwie (Strzelecka 2008). Być może było to spowodowane odgórnymi zaleceniami, właściwymi dla panującego ówcześnie 
paradygmatu taktyki kryminalistycznej praktykowanego w państwach bloku wschodniego na wzór ZSRR. Tematyka homoseksualizmu oraz przestępstw dotyczących tej grupy społecznej stanowiła tabu i była skutecznie pomijana. Ponadto milicja nie miała w zwyczaju informować opinii publicznej poprzez komunikaty o popełnionej zbrodni, dopóki sprawca pozostawał niewykryty. Prowadziłoby to do osłabienia pozycji ówczesnych organów ścigania, ukazania ich jako nieudolnych. $Z$ pełnym zaangażowaniem informowano natomiast o sukcesach, co miało przede wszystkim wymiar propagandowy. Obecnie komunikaty o dokonaniu zbrodni prezentowane są za pośrednictwem radia, telewizji i prasy, a dodatkowo społeczeństwo obywatelskie - żądne sprawiedliwości - często samo wykazuje inicjatywę i dopomaga w ujęciu zabójcy. Wspomniany artykuł prasowy, w którym zamieszczono portret pamięciowy podejrzanego, był jednak tendencyjny, wręcz prześmiewczy, zawierał słownictwo nacechowanie emocjonalnie dalekie od obiektywizmu wymaganego przy formułowaniu komunikatów prasowych i współcześnie zostałby uznany za niezgodny z etyką dziennikarską (Interwencja 2013).

Interesującą kwestią korelującą z modus operandi, stanowiącą jednocześnie rozwinięcie dwóch ostatnich punktów schematu działania sprawcy opracowanego przez autora, jest sposób upłynnienia skradzionych dóbr materialnych. Wśród nich znalazły się m.in. magnetowid, aparat fotograficzny, radioodtwarzacz, biżuteria (sygnety, obrączki), odzież (kożuch, skórzane kurtki, koszula), pieniądze, telewizor. Uprzednio zaznaczono, że skradzione przedmioty były wyznacznikiem zamożności ich posiadacza. Cześć z nich w realiach PRL nie była możliwa do nabycia bezpośrednio, ale wymagała dysponowania talonem, dolarami (w przypadku zakupów w PEWEX-ie) bądź nabycia za granicą. Z tego względu zastanawiający jest dalszy los wymienionych ruchomości, miejsce i sposób ich zbycia. Należałoby w miejscach, gdzie fizycznie zachodzi taka możliwość, tj. na giełdach, bazarach, w komisach i podobnych lokalizacjach, w których złodziej może dokonać korzystnej dla siebie transakcji, rozpytywać, czy pojawił się mężczyzna o sylwetce zgodnej z portretem pamięciowym. Jeśli jednak przedmioty te zostały wywiezione poza obszar województwa łódzkiego bądź za granicę, to w takiej sytuacji próżno szukać śladów tych transakcji, gdyż na wspomniane dobra był znaczny popyt, a skala ujawnionych kradzieży-niewielka.

W kontekście kradzieży mienia z miejsca przestępstwa istotna będzie próba udzielenia odpowiedzi na pytanie o mobilność sprawcy i posiadanie ewentualnych wspólników. Wynoszenie z mieszkania wielkogabarytowych przedmiotów niosło ze sobą ryzyko zauważenia przez sąsiadów, a oddalanie się z tymi przedmiotami od bloku, w którym zamieszkiwała ofiara - przez patrol milicyjny. Przemieszczanie się $\mathrm{z}$ telewizorem $\mathrm{w}$ późnych godzinach nocnych ulicami osiedla stanowiłoby niecodzienny widok i wzbudziło zainteresowanie potencjalnych świadków. Dodatkowo należy przyjrzeć się ilości skradzionych dóbr. Wymusza to pytanie o powrót sprawcy do mieszkania ofiary (może to sugerować fakt kradzieży kluczy, co umożliwiałoby zamknięcie drzwi na klucz i przyjście po raz kolejny, aby zabrać 
kolejne rzeczy wchodzące w skład majątku ofiary). Intrygującym zagadnieniem w obliczu sformułowanych spostrzeżeń jest sposób przenoszenia przedmiotów z lokali zamordowanych mężczyzn w inne miejsce, znane wyłącznie sprawcy. O ile podróż nocną komunikacją miejską czy taksówką z torbą lub walizkami, do których spakowano cenne obiekty, nie wzbudzałaby większych podejrzeń, to dzierżenie w rękach telewizora czy magnetowidu stanowiłoby pewne kuriozum. $\mathrm{Z}$ tego powodu rodzi się sugestia co do transportu tych rzeczy z użyciem pojazdu mechanicznego. Czy zatem sprawca w tak młodym wieku posiadał pojazd, czy może samochód należał do bliskiej osoby, członka rodziny (np. matki, o której sam wspomniał)? Jest prawdopodobne, że zabójca posiadał prawo jazdy, gdyż w poprzednim ustroju prawo jazdy można było uzyskać w wieku 16 lat, a nauka jazdy odbywała się w ośrodkach Ligi Obrony Kraju przy szkołach podstawowych/ średnich. Niewykluczone również, że sprawca miał wspólników, ułatwiających mu przestępczy tryb życia, użyczających mu pojazd i upłynniających mienie, jakie zrabował od swoich ofiar. Jeden ze świadków zeznał, iż w okresie około roku od ostatniego morderstwa widział „Romana” w pojeździe na ulicy. Nie zdążył jednak zanotować numerów rejestracyjnych i nie sprecyzował, czy osobnik ten prowadził pojazd, czy też znajdował się w nim jako pasażer (Masłowski, Urazińska, Walczyk 2010).

Na ogólnym tle sprawy, poza opisanym wcześniej schematem działania sprawcy, można wyodrębnić jeszcze jeden zaobserwowany cykl: powtarzalność miesięcy, w jakich zostały dokonane zabójstwa - trzy nastąpiły w lipcu, dwa w lutym, a jedno w listopadzie. Z punktu widzenia profilera kryminalnego wybór miesięcy na określoną literę i powtarzalność w przypadku wymienionych z pewnością ma znaczenie w budowaniu profilu psychologicznego sprawcy. Część seryjnych morderców wyróżnia się charakterystycznym elementem, ściśle zespolonym z własnym modus operandi - przejawia się to w doborze określonego narzędzia zbrodni (Paweł Tuchlin, Henryk Moruś), odgrywaniu pewnej roli społecznej, np. osoby cieszącej się zaufaniem publicznym (Mieczysław Zub) (Mieczysław... 2017), posługiwaniu się mundurem milicjanta $\mathrm{w}$ celu wywołania $\mathrm{u}$ ofiary fałszywego zaufania i poczucia bezpieczeństwa (umożliwiających sprawne przeprowadzenie ataku), a także w wyborze pory roku i dnia na dokonanie zabójstwa. Wspomniany wyżej dobór miesięcy mógł zatem być nieprzypadkowy. Z perspektywy występowania zaburzeń psychicznych atakowanie ofiar w wybrane miesiące może być spowodowane faktem wystąpienia urazu psychicznego w przeszłości - sprawca odreagowuje napięcie, odgrywając rolę z okresu wczesnej młodości, kiedy to miał zostać wykorzystany seksualnie przez wychowawcę. Dopuszczając inne wytłumaczenie, można zakładać, że przestępcza aktywność przypadająca akurat na te miesiące roku spowodowana była okresowym przebywaniem mężczyzny na terenie Łodzi, jeśli np. byłby delegowany z zakładu pracy na kilka tygodni poza stałe miejsce pracy i zamieszkania. Pomijając rok 1989, w którym miały miejsce dwa morderstwa, to rok wcześniej i w późniejszych latach zbrodnie następowały 
cyklicznie raz do roku. Tłumaczyłoby to fakt zachowania anonimowości przez sprawcę, jeśli mimo dobrej orientacji we mieście przebywał tam tylko cyklicznie, nie zamieszkując go stale - to dodatkowy czynnik utrudniający pracę ówczesnych śledczych. Mając powyższe na uwadze, dobrym posunięciem byłoby sprawdzenie zakładów pracy spoza województwa łódzkiego odnośnie do delegowania pracowników do zakładów mieszczących się na jego terenie. Nie zawsze jednak takie rozpoznanie bywa skuteczne - w historii polskiej kryminalistyki zapisał się przykład Joachima Knychały, który pozostawał nieuchwytny przez okres kilku lat, podczas gdy w kopalni, gdzie znalazł zatrudnienie, wpisywany był zaocznie przez brygadzistę zmiany w przypadku wyrobienia nadgodzin bądź odrobienia służby wcześniej (Widacki 2006, 57).

\section{PODSUMOWANIE}

Z uwagi na wielowątkowość badanej sprawy relewantne było skupienie się na jej najbardziej istotnych szczegółach, odnosząc się do założeń sformułowanych na wstępie niniejszego artykułu oraz kwestii, które należałoby poddać ponownej ocenie w związku z rozwojem metod badawczych wraz z upływem czasu, jaki minął od zapoczątkowania ciągu niewyjaśnionych zabójstw, odnotowanego w dziejach polskiej kryminalistyki i kryminologii.

Oczywiście, niniejsze opracowanie odnośnie przedstawionych hipotez ma wymiar czysto teoretyczny, opiera się jednak na stosownej literaturze naukowej. Impulsem do powstania artykułu są działania operacyjne zmierzające do wykrycia sprawcy, podjęte przez łódzki Zespół ds. Przestępstw Niewykrytych - Archiwum X. Materiały zgromadzone podczas postępowań przygotowawczych związanych $\mathrm{z}$ omawianą serią morderstw nie są dostępne dla autora, ponieważ w świetle przepisów Kodeksu postępowania karnego nie jest on osobą uprawnioną do zapoznania się z materiałem dowodowym, $\mathrm{z}$ uwagi na wznowienie śledztwa. $\mathrm{Z}$ tych względów zestawia on powszechnie dostępne informacje dotyczące poruszanego zagadnienia, dokonując ich analizy przy wykorzystaniu współczesnych osiągnięć naukowych we wspomnianych dziedzinach. W tym miejscu wypada zasygnalizować, że analizowane przypadki można by rozpatrywać w bardziej rozległym zakresie niż to uczynił autor, jednak wykroczyłoby to znacznie poza ramy objętościowe tego artykułu.

$\mathrm{Z}$ biegiem lat i postępem procesów fizjologicznych krąg osób mogących wnieść informacje przydatne dla pracowników wspomnianej komórki Archiwum $\mathrm{X}$ będzie ulegał zmniejszeniu. $\mathrm{Z}$ tego względu ponawianie komunikatów za pośrednictwem mediów, tak jak miało to miejsce za sprawą Telewizji Publicznej i Polsatu, jest bardzo pożądane, zwłaszcza że każda osoba zgłaszająca się i dzieląca własną wiedzą o tamtych wydarzeniach może liczyć na anonimowość. Należy podkreślić, że z prawno-karnego punktu widzenia ostatnia ze zbrodni tej 
największej niewyjaśnionej serii morderstw w historii polskiej kryminalistyki przedawni się w $2023 \mathrm{r}$.

Profesor Brunon Hołyst pytany w kontekście omawianej sprawy i ryzyka związanego z działaniem instynktu sprawcy o to, czy możliwe jest, aby popęd ten zanikł, odpowiedział: „Nie jest wykluczone, ale być może, że jeszcze za kilka lat wróci do procederu zabijania" (Interwencja 2013).

\section{BIBLIOGRAFIA}

Bieńkowska, Ewa. 2000. Wiktymologia. Zarys wykładu. Warszawa: Wydawnictwo Zrzeszenia Prawników Polskich.

Choromańska, Agnieszka, Dorota Mocarska. 2009. Dewiacje i przestępstwa seksualne - klasyfikacja, aspekty prawne. Szczytno: Wydawnictwo Wyższej Szkoły Policji w Szczytnie.

Chróścielewski, Edmund. 1965. „Zabójstwo na tle zazdrości u homoseksualisty”. Archiwum Medycyny Sadowej, Psychiatrii Sadowej i Kryminologii 17 (2): 185-191.

Gierowski, Józef, Teresa Jaśkiewicz-Obydzińska. 2002. Zabójcy i ich ofiary. Psychologiczne podstawy profilowania nieznanych sprawców zabójstw. Kraków: Wydawnictwo Instytutu Ekspertyz Sądowych.

Godlewski, Julian. 1987. „Typologia zgwałcen”. Psychiatra Polski 21 (4): 296-301.

Hanausek, Tadeusz. 1978. „Modus operandi i alibi”. Studia Kryminologiczne, Kryminalistyczne i Penitencjarne 8: 200-227.

Hanse, Edgar. 1968. „Niektóre zagadnienia prawne, kryminalistyczne i penitencjarne gwałtów homoseksualnych wśród więźniów”. Archiwum Medycyny Sądowej i Kryminologii 18 (2): 203-207.

Hazelwood, Robert, John Douglas. 1980. „The Lust Murderer”. FBI Law Enforcement Bulletin 4: 18-22.

Heitzman, Janusz. 2002. Stres $w$ etiologii przestęstw agresywnych. Kraków: Wydawnictwo Uniwersytetu Jagiellońskiego.

Hołyst, Brunon. 2000. Wiktymologia. Warszawa: Wydawnictwo Prawnicze PWN.

Konieczny, Jerzy, Maciej Szostak. 2011. Profilowanie Kryminalne. Warszawa: Wolters Kluwer.

Konopka, Tomasz, Krzysztof Woźniak, Jerzy Kunz, Dagna Frączek, Joanna Kozioł. 2009. „Zabójstwa z głębokimi obrażeniami narządów rodnych”. Archiwum Medycyny Sądowej i Kryminologii (59): 78-84.

Kulicki, Mariusz, Violetta Kwiatkowska-Wójcikiewicz, Leszek Stępka. 2009. Kryminalistyka. Toruń: Wydawnictwo Naukowe Uniwersytetu Mikołaja Kopernika.

Leszczyński, Juliusz, Tadeusz Hanausek. 1995. Kryminologiczne i kryminalistyczne problemy zabójstw z lubieżności. Warszawa: Wydawnictwo ABC.

Lipowska-Teutsch, Anna, Ewa Ryłko. 2007. Przemoc motywowana uprzedzeniami. Przestęstwa z nienawiści. Kraków: Towarzystwo Interwencji Kryzysowej.

McCabe, Marita P., Michelle Wauchope. 2005. „Behavioral characteristics of men accused of rape: Evidence for different types of rapists". Archives of Sexual Behaviour 34 (2): 241-253.

Pastwa-Wojciechowska, Beata. 2013. Psychopaci - sprawcy przestępstw seksualnych. Gdańsk: Harmonia Universalis.

Ptak, Joanna. 2015. „Szczególne okrucieństwo jako znamię przestępstwa zabójstwa”. Prokuratura i Prawo 9: 96-110.

Rydzek, Tadeusz. 1984. „Zabójstwa połączone z maskowaniem zwłok w świetle badań”. Archiwum Medycyny Sadowej i Kryminologii 34 (2): 89-105. 
Szaszkiewicz, Maciej. 2002. Model opracowywania charakterystyki psychofizycznej nieznanego sprawcy zabójstwa. Kraków: Wydawnictwo Instytutu Ekspertyz Sądowych.

Tomsen, Stephen A. 2002. Hatred, Murder and Male Honour: Anti-homosexual Homicides in New South Wales. Sydney: Australian Institute of Criminology.

Turvey, Brent. 2001. Criminal Profiling. An Introduction to Behavioral Evidence Analysis. San Diego: Academic Press.

Widacki, Jan. 2006. Zabójca z motywów seksualnych. Studium przypadku. Kraków: Oficyna Wydawnicza AMF.

Widacki, Jan, Tadeusz Widła, Jerzy Konieczny. 2012. Kryminalistyka. Warszawa: C.H. Beck.

Włodarczyk, Renata. 2007. „Kryminalistyczne ślady biologiczne portretem sprawców zabójstw i innych przestępstw”. Roczniki Pomorskiej Akademii Medycznej w Szczecinie (53) 2: 159-165.

Wnorowski, Jerzy. 1978. Sposób działania jako środek identyfikacji sprawcy przestęstwa. Warszawa: Wydawnictwo Prawnicze.

Zdzisław, Marek. 1986. „Homoseksualiści jako ofiary i sprawcy przestępstw kryminalnych”. Archiwum Medycyny Sądowej i Kryminologii 36 (1): 21-26.

\section{Strony internetowe i inne materiały}

Akcja ,Hiacynt”. 2017. https://pl.wikipedia.org/wiki/Akcja_Hiacynt [dostęp 24.03.2017].

Interwencja. Lódzka seria zabójstw homoseksualistów. 2013. Polsat News.

Kasperska, Agnieszka. 2014. Zbrodnie sprzed lat. Zabójstwo „Wandy”, króla lubelskich gejów. http://www.kurierlubelski.pl/artykul/3498099,zbrodnie-sprzed-lat-zabojstwo-wandy-krola-lubelskich-gejow,id,t.html [dostęp 24.03.2017].

Leszek Pękalski. 2017. https://pl.wikipedia.org/wiki/Leszek_Pękalski [dostęp 24.03.2017].

Magazyn Kryminalny 997. 13 marca 2008. TVP.

Magazyn Kryminalny 997. 9 kwietnia 2008. TVP.

Magazyn Kryminalny 997. 8 maja 2008. TVP.

Masłowski, Marcin, Agnieszka Urazińska, Jerzy Walczyk. 2010. „Zdarzyło się w Łodzi”. Mordowat gejów na Fabrycznym. http://lodz.wyborcza.pl/lodz/1,35136,7956685,_Zdarzylo_sie_w_Lodzi_Mordowal_gejow_na_Fabrycznym.html [dostęp 24.03.2017].

Mieczysław Zub. 2017. https://pl.wikipedia.org/wiki/Mieczysław_Zub [dostęp 24.03.2017].

Milcke, Mikołaj. 2015. Jak generał Kiszczak walczył z gejami. Rwanie hiacyntów. https://www.polityka.pl/tygodnikpolityka/historia/1641393,1,jak-general-kiszczak-walczyl-z-gejami [dostęp 24.03.2017].

Morderca gejów z Łodzi. 2017. https://pl.wikipedia.org/wiki/Morderca_gejów_z_Łodzi [dostęp 24.03.2017].

Omyliński, Janusz. 2012. Kod seks-czatów i slang gejów. Tajemny język branży. http://natemat. pl/4759,kod-seks-czatow-i-slang-gejow-tajemny-jezyk-branzy [dostęp 24.03.2017].

Pierzchała, Wiesław. 2007. Łódzkie Archiwum X na tropie mordercy gejów. http://lodz.naszemiasto. pl/archiwum/lodzkie-archiwum-X-na-tropie-mordercy-gejow,1585528,art,t,id,tm.html [dostęp 24.03.2017].

Strzelecka, Katarzyna. 2008. Sprawa z „Archiwum X”. Zabójca z pikiety. http://wiadomosci.onet.pl/ kiosk/sprawa-z-archiwum-X-zabojca-z-pikiety/16v4m [dostęp 24.03.2017].

Zabójca z pikiety. 2017. http://www.magazyndetektyw.pl/zabojca-z-pikiety [dostęp 24.03.2017]. 
Tomasz Berdzik

\title{
THE ANALYSIS OF MODUS OPERANDI AND THE ATTEMPT TO DETERMINE THE PERPETRATOR'S MOTIVES BASED ON THE CASE STUDY OF THE UNEXPLAINED CRIME WITH THE CODENAME 'PARTNER'
}

\begin{abstract}
The article is an attempt to interpret the information collected on the basis of the contents of scientific materials in confrontation with widely available press reports and media files regarding the largest unexplained series of murders in the history of Polish forensic science, which for the sake of the investigation are the case messages authorized by the authorities working on the case being a fraction of the material collected since the start of the investigation, but sufficient to satisfy the right to public information, as well as social curiosity. Based on the above documentation, some questions have been posed that get answers because of an incomplete outline of the perpetrators and especially individuals who handle not fluent in fields of study such as criminology, forensics, forensic medicine and criminal psychology. Some changes that take place because of the passage of time and new threads around the investigation have been discussed.
\end{abstract}

Keywords: homosexual serial killer, codename 'Partner', Gay killer from Łódź, crimes from X Archive. 